Discussion Paper No. 10-018

The Effects of the Bologna Process on College Enrollment and Drop-out Rates

Julia Horstschräer and Maresa Sprietsma

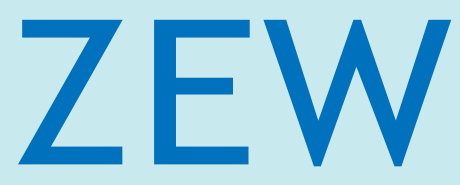

Zentrum für Europäische Wirtschaftsforschung $\mathrm{GmbH}$

Centre for European

Economic Research 
Discussion Paper No. 10-018

\title{
The Effects of the Bologna Process on College Enrollment and Drop-out Rates
}

\author{
Julia Horstschräer and Maresa Sprietsma
}

Download this ZEW Discussion Paper from our ftp server:

ftp://ftp.zew.de/pub/zew-docs/dp/dp10018.pdf

Die Discussion Papers dienen einer möglichst schnellen Verbreitung von neueren Forschungsarbeiten des ZEW. Die Beiträge liegen in alleiniger Verantwortung der Autoren und stellen nicht notwendigerweise die Meinung des ZEW dar.

Discussion Papers are intended to make results of ZEW research promptly available to other economists in order to encourage discussion and suggestions for revisions. The authors are solely responsible for the contents which do not necessarily represent the opinion of the ZEW. 


\section{Non-technical summary}

The Bologna Process was introduced in the member states of the European Union in 1999 with the aim of creating a European Higher Education Area. The main component of the reform was the replacement of the existing national systems of higher education degrees with a homogeneous Bachelor-Master system. The idea was that the comparability of higher education degrees should improve student and labor force mobility, generate competition between universities and thus increase international competitiveness of the European system of higher education.

In certain countries, an additional political objective was to increase the number of higher education graduates and thereby address the lack of highskilled personnel. In many countries including Germany, the Bachelor degree can be obtained in a shorter period of time and is therefore less costly than the traditional national university degrees. This could encourage more students to invest in higher education and to finish their degrees. On the contrary, the returns to the new degrees are still uncertain. According to human capital theory, direct and indirect costs of studying are a major determinant of the decision to pursue tertiary education. It is therefore unclear whether the reform has an effect on college enrollment and drop-out rates.

Existing evidence on the impact of the Bologna reform on higher education enrollment and drop-out rates is limited. This is due to the fact that the reform has only been implemented very recently and that it was too early so far to measure its effects. In this paper, using administrative data on all German students from 1998 to 2006, we estimate the short-term effects of the implementation of the Bachelor degree on student enrollment and drop-out rates at the department level. We use differences in the timing of the implementation of the Bachelor degrees at the department level to identify the effects of the reform.

We find that the introduction of the Bachelor degree has no significant impact on enrollment or drop-out rates for most subjects. The reform therefore does not seem to have changed the incentives to pursue higher education at this stage. We do find significantly negative effects of the Bachelor implementation on enrollment for the subjects of electrical, mechanical and industrial engineering as well as for physics. We interpret this result as a possible sign of students avoiding the new degrees in these subjects because the traditional German engineering degrees have a very good reputation. If this is the case, the observed negative effect should eventually vanish as the traditional degrees are increasingly replaced by Bachelor programs. Hence, we should keep in mind that the effects of the reform on the number of first-year students as well as on drop-out rates may be different in the long-run, when all departments will have implemented the reform. 


\section{Das Wichtigste in Kürze}

Der Bologna Prozess wurde von den EU-Mitgliedsstaaten im Jahr 1999 mit dem Ziel eines einheitlichen europäischen Hochschulraumes beschlossen. Der Kern dieser Reform besteht darin, die unterschiedlichen nationalen Hochschulabschlüsse durch europaweit homogene Bachelor- und Masterabschlüsse zu ersetzten. Die vergleichbaren Abschlüsse sollen die Mobilität von Studenten und Hochschulabsolventen fördern sowie Wettbewerb zwischen den Hochschulen herstellen, um so den innereuropäischen Wettbewerb zu stärken.

In einigen Ländern soll die Reform auch dazu genutzt werden, die Anzahl der Hochschulabsolventen zu erhöhen, um so dem drängenden Problem des Fachkräftemangels entgegen zu wirken. In Deutschland, wie auch in vielen anderen europäischen Ländern, kann der berufsqualifizierende Bachelor-Abschluss in kürzerer Zeit erworben werden und ist somit sowohl für die Studenten als auch für den Staat kostengünstiger als die bisherigen nationalen Hochschulabschlüsse. Dies könnte dazu führen, dass mehr Studenten ein Hochschulstudium aufnehmen und auch einen Hochschulabschluss erwerben. Andererseits sind die Bildungsrenditen der neuen Hochschulabschlüsse noch nicht bekannt. Entsprechend der Humankapitaltheorie sind direkte und indirekte Kosten in der Tat eine wichtige Determinante für die Wahl eines Hochschulstudiums. Daher ist vorab unklar, ob die Reform einen Effekt auf die Zahl der Studienanfänger oder auf die Zahl der Studienabbrecher hat.

Bisher besteht nur wenig Evidenz zur Wirkung der Bachelor Einführung auf die Zahl der Studienanfänger und Studienabbrecher, da die Reform erst kürzlich umgesetzt wurde. Anhand von neu verfügbaren administrativen Daten aller Studenten Deutschlands von 1998 bis 2006 können wir erstmals in diesem Artikel die kurzfristigen Effekte der Einführung des Bachelor-Abschlusses auf die Zahl der Studienanfänger und Studienabbrecher auf Fachbereichsebene schätzen. Für die Identifikation dieser Effekte nutzen wir die zeitlichen Unterschiede, mit der die Fachbereiche auf die neuen Bachelor Abschlüsse umgestellt haben.

Die Ergebnisse zeigen für die meisten Fächer keine signifikanten Auswirkungen der Reform auf die Zahl der Studienanfänger als auch auf die Zahl der Studienabbrecher. Die Reform scheint also die Anreize zur Aufnahme eines Studiums in der Regel nicht verändert zu haben. Ausnahmen sind jedoch die Fächer Elektrotechnik, Bau- und Machinenbauingenieurwesen sowie Physik. In diesen Fächern hat sich die Anfängerzahl im Zuge der Reform signifikant verringert. Eine mögliche Interpretation dazu ist, dass die Studenten dieser Fächer die neuen Abschlüsse meiden, da die bisherigen deutschen Diplom-Abschlüsse in den ingenieur- und naturwissenschaftlichen Fächern einen sehr guten Ruf genießen. Dieses strategische Verhalten der Studenten kann allerdings nur in der Übergangsphase der Reform auftreten, so dass die langfristigen Effekte sowohl auf die Zahl der Anfänger als auch auf die Zahl der Abbrecher von den hier beschriebenen Ergebnissen abweichen können. 


\title{
The Effects of the Bologna Process on College Enrollment and Drop-out Rates
}

\author{
Julia Horstschräer and Maresa Sprietsma*†
}

March 26, 2010

\begin{abstract}
This paper estimates the short-term effects of the introduction of the Bachelor degree in the framework of the Bologna Process on college enrollment and drop-out rates. We use variation in the timing of the Bachelor implementation at the department level to identify the effect of the reform based on longitudinal administrative student data from Germany. We find no significant effects on college enrollment or drop-out rates for most subjects.
\end{abstract}

JEL-Classification: I28, I21, C23

Keywords: higher education, college enrollment, drop-out, Bologna Process

\footnotetext{
${ }^{*}$ Centre for European Economic Research (ZEW), P.O. Box 103443, D-68034 Mannheim, Germany; Julia Horstschräer (corresponding author) - e-mail: hortschraeer@zew.de, phone: +49-621-1235-196, fax: +49-621-1235-225; Maresa Sprietsma - e-mail: sprietsma@zew.de.

${ }^{\dagger}$ Acknowledgements: For their comments on an earlier version of this paper we thank our colleagues at the ZEW Andrea M. Mühlenweg and Verena Niepel. The usual disclaimer applies. Furthermore, we are grateful to Dr. Simone Wagner (Statistical Office of Bavaria) and Manuel Boos (Statistical Office of Hesse) for their advice and support regarding the administrative student data. Julia Horstschräer thanks the German Federal Ministry of Education and Research for financial support (reference number: 01 JG 0914).
} 


\section{Introduction}

The Bologna Process was introduced in the member states of the European Union in 1999 with the aim of creating a European Higher Education Area. The main component of the reform was the replacement of the existing national systems of higher education degrees with a homogeneous Bachelor-Master system. The idea was that the comparability of higher education degrees should improve student and labor force mobility, generate competition between universities and thus increase the international competitiveness of the European system of higher education.

In certain countries, an additional political objective was to increase the number of higher education graduates and thereby address the lack of highskilled personnel. In many countries including Germany, the Bachelor degree can be obtained in a shorter period of time and is therefore less costly than the traditional national university degrees. This could encourage more students to invest in higher education and to finish their degrees. According to theory, direct and indirect costs of studying are a major determinant of the decision to pursue tertiary education (Becker, 1964). On the contrary, empirical evidence on students' financial constraints with respect to higher education is mixed (Carneiro and Heckman, 2002; Dearden et al., 2004; Vandenberghe, 2007). Moreover, the returns to the new degrees are still uncertain. It is therefore unclear whether the reform has an effect on college enrollment and drop-out rates.

Existing evidence on the impact of the Bologna reform on higher education enrollment and drop-out rates is limited. This is due to the fact that the reform has only been implemented very recently and that it was too early so far to measure its effects. The literature does provide numerous descriptions of the implementation process (e.g Kehm and Teichler, 2006), but to our knowledge causal evidence regarding the impact of the Bologna Process on enrollment and drop-out rates barely exists as yet. An exception is the paper by Portela et al., 2009 , who compute the effect of the Bachelor implementation on the number of applications by department in Portugal. They find that the number of applicants is significantly higher at departments that implemented the Bachelor degree than at those departments still awarding traditional degrees. Using survey data of secondary school graduates in Italy, Cappellari and Lucifora (2009) provide evidence that the enrollment rate increased by $15 \%$ in the period after the reform. Moreover, case studies of Italian universities reveal that the individual probability of dropping out did not change significantly after the implementation of the Bologna reform (Boero et al., 2005; Bratti et al., 2006).

In this paper, using administrative data on all German students from 1998 to 2006, we estimate the short-term effects of the implementation of the Bachelor degree on student enrollment and drop-out rates at the department level. We do not look at graduation rates because it is still too early to assess them. We use differences in the timing of the implementation of the Bachelor degrees at the department level to identify the effects of the reform. Estimating a fixed effects model, we find that the introduction of the Bachelor degree has no significant impact on enrollment or drop-out rates for most subjects at this stage. In the remainder of the paper, we first present the data and descriptive statistics (section 2). Section 3 then provides the identification strategy and 
assumptions, followed by the empirical results and interpretation (section 4). Section 5 concludes.

\section{Data and descriptive statistics}

We use administrative data on all German students collected every academic term from 1998 to $2006^{1}$. For the winter semesters (October to March), the data set includes every enrolled student while for the summer semesters (AprilSeptember) it only consists of students who newly enroll, or change subject or university. In addition, we use institutional data on the quality of universities provided by the $\mathrm{CHE}^{2}$. This data is collected for the purpose of a national ranking of higher education departments and is available for a majority of subjects and universities. The advantage of the administrative student data is that we can observe all students in Germany over a long period of time. The data contain detailed information on the course of studies and some student background variables.

The subjects we consider are selected based on the existence of a minimum number of departments providing a degree in the subject (at least 20) and the availability of CHE data. Subjects in which the reform was not implemented in any department until 2006, such as medicine and law, were excluded from the analysis as well. Students of a teaching degree ('Lehramt') are not considered either, because their degree system has not changed yet. The sample is further restricted to full-time students and students of universities or universities of applied sciences ${ }^{3}$, who pursue a first degree. This means we exclude Master and $\mathrm{PhD}$ students, as well as distance-learning and part-time students. As the data from some years are missing for the federal state of Hamburg, the universities of this state are excluded from the analysis. Due to the absence of an individual panel identifier, we aggregate the data at the level of university departments. In order to obtain a balanced panel of departments, departments opening or closing during the observation period are dropped. Table 1 lists the number of departments included in our analysis for each subject. ${ }^{4}$

The data allow us to calculate the number of first-year students, the share of drop-outs and the percentage of first-year students enrolled in the Bachelor and the traditional degree programs at the department level. The drop-out rate in year $t$ is calculated by dividing the number of second-year students in year $t$ by the number of first-year students in year $t-1$. We thus follow cohorts of first-year students and calculate drop-out rates for each cohort. Due to the one year time lag we need to observe the second-year students, the latest cohort in

\footnotetext{
${ }^{1}$ Statistical Office Germany, Higher Education Statistics.

${ }^{2}$ Centre for Higher Education Development, Germany.

3 i.e. we exclude students at pedagogical, theological, art and music schools.

${ }^{4}$ For the drop-out analysis we use a slightly different sample, as we need to balance the sample only over the years 1998 - 2005. The observation period for the drop-out sample ends with the first-year students of 2005 due to the one year time lag we need to observe the secondyear students. The samples for the analysis of the first-year students and the drop-out sample also differ with respect to the definition of first-year students. For the analysis of first-year students we define students entering the higher education system for the first time as first-year students. In the drop-out sample we consider all students, who are in the first-year of their current studies.
} 
Table 1: Number of departments included in the balanced panel (1998-2006):

\begin{tabular}{l|c|l|c}
\hline & Departments & & Departments \\
\hline \hline All Subjects Pooled & 1034 & German Lang. and Lit. & 51 \\
Biology & 43 & History & 39 \\
Business and Management & 112 & Industrial Engineering & 60 \\
Chemical Engineering & 24 & Information Systems & 37 \\
Chemistry & 52 & Mathematics & 63 \\
Computer sciences & 80 & Mechanical Engineering & 87 \\
Construction Engineering & 55 & Physics & 51 \\
Economics & 32 & Political Science & 37 \\
Electrical Engineering & 89 & Psychology & 42 \\
English Lang. and Lit. & 49 & Sociology & 31 \\
\hline
\end{tabular}

the drop-out analysis are the first-year students of 2005. Because drop-out rates are defined at the level of the departments, students that change university or subject are counted as drop-outs. The drop-out rate is therefore a measure of the capacity of the department to retain its students. Whether they switch or give up studying as a whole cannot be distinguished.

The Bologna reform was implemented in Germany as from the academic year $2000 / 01$. University departments were free to decide in which year they would start offering Bachelor programs. In this paper a department is considered to have implemented the Bachelor reform (Bachelor dummy equals one) if more than $75 \%$ of first-year students are attending a Bachelor program ${ }^{5}$. In the academic year 2006-2007, at the end of the observation period, $53 \%$ of the departments had implemented the Bachelor degree for more than $75 \%$ of their first-year students ${ }^{6}$. Figures A.1 to A.4 show the share of departments that implemented the reform over time by subject. We observe that in most subjects, the Bachelor degree started taking off as from 2003. Moreover, we note that whereas in some subjects the reform shows a relatively long 'pilot' phase in which less than $10 \%$ of departments experiment with the Bachelor degree (A.1), in other subjects the reform was implemented more progressively.

Summary statistics for the number of first-year students and the drop-out rates over all academic years are given in Table 2 and Table 3. The tables also depict the statistics separately for departments that switched to the Bachelor degree and for those that still operate under the traditional degree system. Pooled across all subjects, the Bachelor departments are on average smaller than the departments that have not yet implemented the reform. This is the case for 14 out of the 19 considered subjects. In addition, we observe considerable variation in the average department size by subject. Whereas business and management departments have 174 first-year students on average, history

\footnotetext{
${ }^{5}$ In the transition period, some departments maintained an old study program in parallel to the new Bachelor program. This can lead to changes in the share of Bachelor students around the threshold of $75 \%$. Because it makes little sense to consider these departments as moving in and out of the reform, a department is considered to have implemented the Bachelor reform in all following years once the share of Bachelor students in a department surpassed the threshold of $75 \%$ in a given year.

${ }^{6}$ The observation period for the drop-outs ends with the cohort of the first-year students of 2005 . By then on average only $28 \%$ of the departments had introduced the Bachelor degree.
} 
and chemical engineering departments are the smallest with around 40 first-year students. Drop-out rates display significant differences across subjects as well. The largest drop-out rates of around $33 \%$ are observed in the field of English language and literature as well as in chemistry whereas psychology departments only have an average drop-out rate of around 8\%. Overall and for most subjects, drop-out rates are not different between Bachelor and traditional degree departments. In a few subjects differences exist in either positive or negative directions.

Table 2: Number of first-year students by department, subject and transition to the Bachelor program (1998-2006)

\begin{tabular}{|c|c|c|c|c|c|c|c|c|c|}
\hline & \multicolumn{3}{|c|}{ Pooled } & \multicolumn{3}{|c|}{ Bachelor $=0$} & \multicolumn{3}{|c|}{ Bachelor $=1$} \\
\hline & $\mathrm{N}$ & Mean & $\begin{array}{l}\text { Std. } \\
\text { Dev. }\end{array}$ & $\mathrm{N}$ & Mean & $\begin{array}{l}\text { Std. } \\
\text { Dev. }\end{array}$ & $\mathrm{N}$ & Mean & $\begin{array}{l}\text { Std. } \\
\text { Dev. }\end{array}$ \\
\hline All Subjects Pooled & 9306 & 95.17 & 84.76 & 8251 & 96.54 & 86.53 & 1055 & 84.45 & 68.51 \\
\hline Biology & 387 & 102.94 & 41.80 & 344 & 103.44 & 42.28 & 43 & 98.91 & 37.94 \\
\hline Business and Management & 1008 & 174.09 & 115.58 & 893 & 177.16 & 118.27 & 115 & 150.22 & 88.87 \\
\hline Chemical Engineering & 216 & 40.44 & 28.87 & 184 & 37.63 & 27.45 & 32 & 56.56 & 31.90 \\
\hline Chemistry & 468 & 79.53 & 47.92 & 403 & 78.09 & 49.12 & 65 & 88.42 & 38.80 \\
\hline Computer Sciences & 720 & 109.16 & 90.38 & 623 & 113.72 & 94.79 & 97 & 79.87 & 44.34 \\
\hline Construction Engineering & 495 & 80.05 & 37.65 & 433 & 81.97 & 37.94 & 62 & 66.69 & 32.76 \\
\hline Economics & 288 & 127.74 & 111.82 & 261 & 132.25 & 114.17 & 27 & 84.11 & 74.13 \\
\hline Electrical Engineering & 801 & 85.98 & 63.43 & 723 & 89.23 & 65.23 & 78 & 55.85 & 29.78 \\
\hline English Lang. and lit. & 441 & 59.79 & 48.82 & 375 & 58.42 & 43.54 & 66 & 67.62 & 71.81 \\
\hline German Lang. and Lit. & 459 & 111.95 & 109.10 & 398 & 111.94 & 107.04 & 61 & 112.00 & 122.63 \\
\hline History & 351 & 41.18 & 42.95 & 281 & 38.17 & 39.92 & 70 & 53.24 & 52.02 \\
\hline Industrial Engineering & 540 & 95.77 & 75.17 & 486 & 97.94 & 77.92 & 54 & 76.28 & 38.54 \\
\hline Information Systems & 333 & 71.25 & 38.56 & 282 & 72.34 & 38.37 & 51 & 65.24 & 39.42 \\
\hline Mathematics & 567 & 54.72 & 55.63 & 523 & 51.98 & 49.98 & 44 & 87.32 & 96.08 \\
\hline Mechanical Engineering & 783 & 124.93 & 113.67 & 701 & 127.47 & 117.62 & 82 & 103.24 & 68.27 \\
\hline Physics & 459 & 71.69 & 47.66 & 420 & 72.10 & 47.85 & 39 & 67.31 & 45.94 \\
\hline Political Sciences & 333 & 76.54 & 62.73 & 300 & 78.41 & 64.84 & 33 & 59.48 & 34.78 \\
\hline Psychology & 378 & 66.57 & 28.29 & 368 & 66.83 & 28.25 & 10 & 57.00 & 29.69 \\
\hline Sociology & 279 & 73.26 & 56.56 & 253 & 74.60 & 57.43 & 26 & 60.19 & 46.13 \\
\hline
\end{tabular}

\{Note: Bachelor $=1$ if if more than $75 \%$ of first-year students are attending a Bachelor program in the department. 
Table 3: Drop-out rates by department, subject and transition to the Bachelor program (1998-2006)

\begin{tabular}{|c|c|c|c|c|c|c|c|c|c|}
\hline & \multicolumn{3}{|c|}{ Pooled } & \multicolumn{3}{|c|}{ Bachelor $=0$} & \multicolumn{3}{|c|}{ Bachelor $=1$} \\
\hline & $\mathrm{N}$ & Mean & $\begin{array}{l}\text { Std. } \\
\text { Dev. }\end{array}$ & $\mathrm{N}$ & Mean & $\begin{array}{l}\text { Std. } \\
\text { Dev. }\end{array}$ & $\mathrm{N}$ & Mean & $\begin{array}{l}\text { Std. } \\
\text { Dev. }\end{array}$ \\
\hline All Subjects Pooled & 8496 & 0.21 & 0.27 & 7980 & 0.21 & 0.27 & 516 & 0.21 & 0.18 \\
\hline Biology & 344 & 0.13 & 0.10 & 323 & 0.13 & 0.09 & 21 & 0.24 & 0.13 \\
\hline Business and Management & 912 & 0.10 & 0.22 & 866 & 0.10 & 0.22 & 46 & 0.09 & 0.17 \\
\hline Chemistry & 424 & 0.32 & 0.14 & 385 & 0.32 & 0.14 & 39 & 0.36 & 0.17 \\
\hline Chemical Engineering & 184 & 0.24 & 0.22 & 165 & 0.24 & 0.22 & 19 & 0.23 & 0.21 \\
\hline Computer Sciences & 648 & 0.20 & 0.15 & 601 & 0.20 & 0.14 & 47 & 0.18 & 0.19 \\
\hline Construction Engineering & 440 & 0.19 & 0.14 & 411 & 0.19 & 0.14 & 29 & 0.20 & 0.13 \\
\hline Economics & 280 & 0.28 & 0.22 & 271 & 0.29 & 0.22 & 9 & 0.26 & 0.17 \\
\hline Electrical Engineering & 736 & 0.18 & 0.62 & 696 & 0.18 & 0.63 & 40 & 0.22 & 0.14 \\
\hline English Lang.and Lit. & 400 & 0.33 & 0.19 & 356 & 0.34 & 0.19 & 44 & 0.23 & 0.17 \\
\hline German Lang.and Lit. & 408 & 0.29 & 0.21 & 380 & 0.30 & 0.21 & 28 & 0.17 & 0.15 \\
\hline History & 336 & 0.30 & 0.38 & 293 & 0.31 & 0.41 & 43 & 0.25 & 0.12 \\
\hline Industrial Engineering & 504 & 0.18 & 0.20 & 483 & 0.18 & 0.19 & 21 & 0.15 & 0.26 \\
\hline Information Systems & 304 & 0.13 & 0.15 & 280 & 0.13 & 0.15 & 24 & 0.12 & 0.17 \\
\hline Mathematics & 512 & 0.31 & 0.20 & 491 & 0.31 & 0.20 & 21 & 0.32 & 0.12 \\
\hline Mechanical Engineering & 728 & 0.17 & 0.18 & 690 & 0.17 & 0.17 & 38 & 0.18 & 0.25 \\
\hline Physics & 424 & 0.25 & 0.13 & 405 & 0.25 & 0.13 & 19 & 0.24 & 0.15 \\
\hline Political Sciences & 312 & 0.20 & 0.19 & 297 & 0.20 & 0.19 & 15 & 0.15 & 0.09 \\
\hline Psychology & 344 & 0.08 & 0.12 & 343 & 0.08 & 0.12 & 1 & 0.01 & 0.00 \\
\hline Sociology & 256 & 0.28 & 0.1 & 244 & 0.28 & 0.14 & 12 & 0.23 & 0.10 \\
\hline
\end{tabular}

\{Note: Bachelor $=1$ if if more than $75 \%$ of first-year students are attending a Bachelor program in the department. 


\section{Estimation strategy}

We estimate the number of first-year students and the drop-out rates per department as a function of the implementation of the Bachelor degree in a fixed effects panel setting. The department fixed effects control for all time-constant observed and unobserved department characteristics. For instance, these could include regional differences in the higher education management, differences between subjects or differences in the quality of the management and prestige at the university or department level. Year dummies are included to capture enrollment trends over time that may be related to e.g. changes in the expectations as to economic activity (a measure of the expected opportunity costs of studying) or to variation in the number of secondary school graduates that have acquired the formal right to attend higher education.

The estimated equation thus reads:

$$
y_{i t}=\beta_{1} B A C H E L O R_{i t}+\beta_{2} \text { Fee }_{i t}+\beta_{3} Y e a r_{t}+v_{i}+\epsilon_{i t}
$$

Where $y_{i t}$ is the number of enrolled students and respectively the dropout rate at department $i$ in year $t, B A C H E L O R_{i t}$ represents an indicator variable equal to one if the department implemented the Bachelor degree ${ }^{7}, v_{i}$ the department fixed effects and $Y e a r_{t}$ represent the year dummies. We also include an indicator for the introduction of tuition fees $F e e_{i t}$, as two federal states have introduced fees in $2006 .{ }^{8}$ This equation is estimated pooled over all subjects as well as separately for each subject within a balanced panel of departments so that $\beta_{1}$ identifies the within departments effects of the Bachelor introduction. Heteroskedasticity robust standard errors are clustered by department to allow for within department serial correlation in the error terms $\epsilon_{i t}$. The analyses by subject allow us to observe potential differences in the impact of the reform for different subjects.

In the pooled regression, we additionally control for the number of departments in each subject per year (before balancing the panel) whereas in the separate estimations per subject, variation in the number of departments is captured by the year dummies. Because departments that open up during the observation period are not taken into account in the analysis, we also estimate whether the share of departments per subject awarding the Bachelor degree affects the total number of first-year students within a subject (in the unbalanced sample). This relation captures the macro effect of the reform, as opposed to the balanced estimation at department level. However, this estimation may be subject to reverse causality, if new departments opened in a given subject independantly of the Bachelor reform.

Our identifying assumption for the analysis on the department level is that the timing of the implementation of the reform is not related to time-varying department characteristics. In order to investigate the plausibility of this assumption, we regress the timing of the reform (that is the year in which the

\footnotetext{
${ }^{7}$ As described above we define that a department has implemented the Bachelor degree once more than $75 \%$ of the first year students are enrolled in a bachelor degree course of study.

${ }^{8}$ Before the year 2006 no German federal state levied tuition fees.
} 
department implemented the Bachelor degree) on observable department characteristics before the reform. In this estimation, we include the average change in the number of first-year students and the average number of first-year students (department size) in the five years before the transition, the share of female students, and the share of students that had vocational training. Furthermore we include department quality measures taken from the CHE data. The available department quality variables vary by subject. Moreover, quality measures are collected only every 3 years, for the first time in 2001, 2002 or 2003 depending on the subject. We use the earliest available department quality measures for each subject. These include the number of PhD students per 10 professors, the research reputation and reputation among professors, the number of citations, the amount of external funding per researcher, as well as students' evaluations of the quality of teaching, organisation, tutoring and infrastructure.

Tables 4 and 5 present the results of this estimation. It appears that except the average change in enrollment in the 5 years before the transition, the department characteristics in general are not significantly correlated with the timing of the transition. Moreover, many of the latter characteristics are unlikely to change quickly over time, and will be captured by the department fixed effects. The enrollment trend is significantly negatively correlated with the year of transition in 6 out of 19 subjects. This means that departments growing faster before the reform (which are most likely also smaller departments as observed in Table 2) tend to implement the Bachelor reform earlier. This may lead to overestimating the effect of the Bachelor reform on the number of first-year students in the fixed effects estimation, because the increase in the number of students related to the department trend is captured by the Bachelor coefficient. 


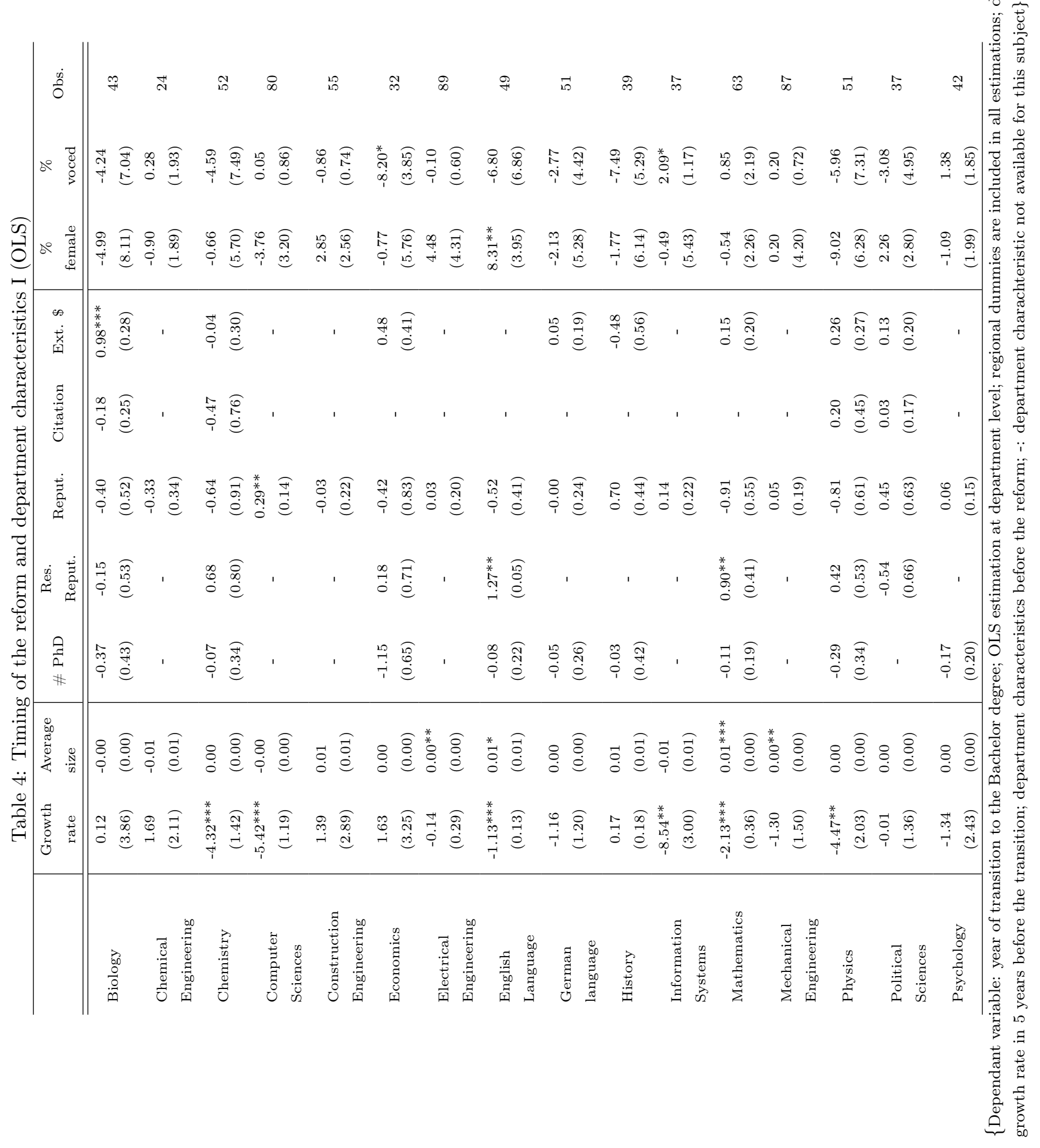




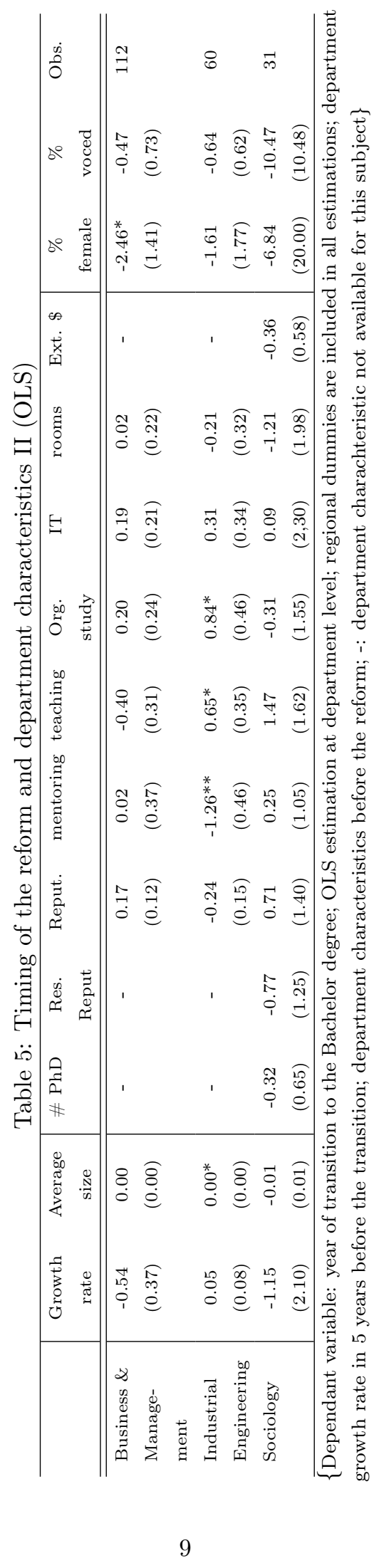




\section{Results}

In this section we present ordinary least squares (OLS) and fixed effects (FE) estimates for the number of first-year students and drop-out rates. The marginal effects are divided by the standard deviation of the outcome variables. The coefficients thus represent percentages of a standard deviation in the outcome variable. This is done to facilitate comparison of the magnitude of the results across disciplines.

Estimating the fixed effects model, we do not find a significant change in the number of first-year students due to the implementation of the Bachelor degree in the pooled sample (Table 6$)^{9}$. This is also true for three quarters of the subjects. The reform therefore does not seem to have changed the incentives to pursue higher education for the moment. The OLS estimation yields a significant negative effect in the pooled sample. If the subject specific effects are significant at all, they are negative in most subjects as well. This difference can be interpreted in line with the findings from Table 4 and Table 5 . There we have seen that the smaller (or faster growing) departments tend to implement the reform earlier. The fixed effects estimation controls implicitly for department size, and should therefore reduce the downward bias associated with initial department size.

We find significantly negative effects of the Bachelor implementation on enrollment for the subjects of electrical, mechanical and industrial engineering as well as for physics whereas the number of first-year students seems to rise with the Bachelor introduction in mathematics. The magnitude of the negative effects is relatively large as it ranges between 15 and $29 \%$ of a standard deviation in the number of first-year students. For the subjects in which the fixed effects coefficients are negative, a possible interpretation is that students avoid the new degrees. In fact, only about 40 to $50 \%$ of the departments in these subjects have implemented the reform yet which means that these subjects are still in the transformation process. As a consequence, students can choose whether they want to apply for a Bachelor or a traditional degree department. Considering the solid reputation of German engineering degrees, students may prefer avoiding the departments proposing the Bachelor degrees in order to pursue the traditionally renowned programs. If that is the case, the departments that have implemented the reform should attract fewer students which results in a negative estimate of the Bachelor implementation. This effect should be transitory because once all departments have introduced the Bachelor degree, avoiding the Bachelor will no longer be an option. Physics is also a subject associated with a high quality education in Germany, so the same arguments could apply. Moreover, students of physics very often aim at a $\mathrm{PhD}$, which means that it is less relevant that a Bachelor can be obtained in a shorter period of time than traditional degrees.

As far as the result for mathematics is concerned, section 3 has shown that for this subject, departments implement the reform earlier if they grew faster before the reform. This may cause the fixed effect coefficients to be overestimated. We are therefore not very confident of the significance of this positive effect.

\footnotetext{
${ }^{9}$ The estimation here is based on the balanced panel. Estimations using the unbalanced panel qualitatively yield the same results.
} 
Table 6: Marginal effects of the Bachelor implementation on the number of first-year students

\begin{tabular}{l|ll|ll|c}
\hline \multirow{2}{*}{} & \multicolumn{2}{|c|}{ OLS } & \multicolumn{2}{c|}{ Fixed Effects } & \multirow{2}{*}{ N } \\
\cline { 2 - 5 } & Marg. & Std. & Marg. & Std. & \\
\hline \hline All Subjects Pooled & Eff. & Err. & Eff. & Err. & \\
\hline Biology & $-0.14^{* * *}$ & $(0.03)$ & -0.02 & $(0.02)$ & 9306 \\
Business and Management & -0.21 & -0.18 & 0.03 & -0.11 & 387 \\
Chemical Engineering & -0.05 & -0.11 & 0.04 & -0.07 & \multirow{2}{*}{1008} \\
Chemistry & $0.69^{* * *}$ & -0.26 & 0.21 & -0.25 & 216 \\
Computer sciences & -0.17 & -0.15 & -0.06 & -0.11 & 468 \\
Construction Engineering & -0.03 & -0.1 & 0.11 & -0.07 & 720 \\
Economics & $-0.37^{* *}$ & -0.14 & -0.02 & -0.08 & 495 \\
Electrical Engineering & $-0.30^{*}$ & -0.16 & -0.11 & -0.1 & 288 \\
English Lang. and Lit. & $-0.64^{* * *}$ & -0.09 & $-0.16^{* *}$ & -0.07 & 801 \\
German Lang. and Lit. & 0.28 & -0.21 & 0.2 & -0.15 & 441 \\
History & 0.15 & -0.17 & 0.17 & -0.17 & 459 \\
Industrial Engineering & $0.32^{*}$ & -0.18 & 0.11 & -0.13 & 351 \\
Information Systems & $-0.68^{* *}$ & -0.15 & $-0.16^{* *}$ & -0.07 & 540 \\
Mathematics & $0.49^{* *}$ & -0.2 & 0.19 & -0.12 & 333 \\
Mechanical Engineering & 0.33 & -0.32 & $0.46^{*}$ & -0.23 & 567 \\
Physics & $-0.58^{* * *}$ & -0.15 & $-0.29^{* * *}$ & -0.08 & 783 \\
Political Science & $-0.39^{* *}$ & -0.18 & $-0.25^{* *}$ & -0.11 & 459 \\
Psychology & $-0.35^{* *}$ & -0.15 & 0.07 & -0.14 & 333 \\
Sociology & $-0.61^{*}$ & -0.33 & -0.07 & -0.19 & 378 \\
\hline Control & -0.02 & -0.19 & -0.12 & -0.2 & 279 \\
\hline
\end{tabular}

\{Control variables: Year dummies and tuition fee dummies; Pooled estimation: Subject dummies and number of faculties per subject (unbalanced) additionally. Marginal effects and robust standard errors standardized by the standard deviation of the dependent variablel\}

A similar overestimation is expected for the four other subjects (chemistry, computer sciences, English language and literature as well as physics), where the growth rate of the department is related to earlier implementation of the Bachelor degree. Moreover, we have seen that department characteristics are generally not correlated with the timing of the reform. Hence, the negative and non significant estimates we find can be interpreted as such.

At the subject level, controlling for year and subject fixed effects, we find that the share of Bachelor departments has a small effect of -0.70 percents of a standard deviation on the total number of first-year students within a subject. This macro effect is only significant at the $10 \%$ level $(\mathrm{p}=0.089)$. Based on our results, we can therefore state that the introduction of the bachelor degree did not increase the number of first-year students, neither within a subject nor at department level.

Regarding the drop-out rate, we find that the Bachelor implementation reduced drop-out rates by $8 \%$ of a standard deviation for all subjects pooled (Table 7$)^{10}$. The magnitude of the effect is small (on average $2 \%$ fewer drop-

\footnotetext{
${ }^{10}$ The estimation here is based on the balanced panel. Estimations using the unbalanced panel qualitatively yield the same results.
} 
outs as the pooled standard deviation in drop-out rates is 0.27 ), and the fixed effects estimations by subject reveal that the effects within subjects are only significantly negative for two subjects: Business and management as well as electrical engineering. In addition, we observe a significantly larger drop-out rate in biology departments that implemented the Bachelor reform.

For most subjects we thus do not identify significant changes in drop-out rates due to the reform. This result is in line with what we would expect for several reasons. First of all, we have seen that the number of first-year students is not significantly affected by the reform and there is no evidence of systematic selection into the Bachelor degrees with respect to family background or students final grades in school either (Muehlenweg et al., 2010). The composition of the student population should therefore have remained the same. Moreover, Vandenberghe (2007) shows that in Germany parental income has no significant effect on the decision to attend tertiary education once family fixed effects are taken into account. As financial resources do not matter much in the decision process, this result suggests that decreasing opportunity costs, as a consequence of a shorter period of time to the degree, must not lead to decreasing drop-outs. In addition, direct and indirect higher education costs have been largely covered by the German state in all regions until today. Hence, we would not expect decreasing opportunity costs related to the shorter duration of the Bachelor degree to cause significantly lower drop-out rates.

As we control for changing outside options by year dummies, an alternative explanation for an effect of the Bachelor implementation on drop-out rates could be interrelated with the reorganisation of the course of studies. But there is some evidence that curricula have not been systematically restructured during the reform (Winter et al., 2010). The existing courses of the traditional degrees were merely split between a Bachelor and a Master program. Furthermore, students did not perceive any changes in the quality of mentoring in the Bachelor program as compared to the traditional degrees (Muehlenweg et al., 2010).

Drop-out rates in business and management and in electrical engineering are affected downwards by the Bachelor implementation. The non-significant coefficients of most other disciplines are negative as well. It is possible that the low share of bachelor departments in the drop-out sample induces the observed negative effects. In fact, we only analyse the drop-out rates until the first-year students of 2005 at the moment and at that time only about $28 \%$ of all departments had implemented the Bachelor degree. Students thus still have the possibility to opt for a traditional degree. If only the more strongly convinced students opt for the new degrees, this could lead to lower drop-out rates. We do not have a satisfying explanation for the positive effect of the Bachelor implementation on the biology drop-out rate. 
Table 7: Marginal effects of the Bachelor implementation on drop-out rates

\begin{tabular}{l|ll|ll|l}
\hline \multirow{2}{*}{} & \multicolumn{2}{|c|}{ OLS } & \multicolumn{2}{c|}{ Fixed Effects } & \multirow{2}{*}{ N } \\
\cline { 2 - 5 } & Marg. & Std. & Marg. & Std. & \\
\hline \hline Eff. & Err. & Eff. & Err. & \\
\hline Biology & $-0.10^{* * *}$ & $(0.03)$ & $-0.08^{* *}$ & $(0.04)$ & 8496 \\
Business and Management & $1.32^{* * *}$ & -0.31 & $1.53^{* * *}$ & -0.35 & 344 \\
Chemical Engineering & -0.12 & -0.2 & $-0.34^{*}$ & -0.2 & 912 \\
Chemistry & 0.12 & -0.29 & -0.02 & -0.32 & 184 \\
Computer sciences & 0.02 & -0.18 & 0.1 & -0.24 & 424 \\
Construction Engineering & $-0.41^{* *}$ & -0.19 & -0.26 & -0.18 & 648 \\
Economics & -0.13 & -0.17 & -0.02 & -0.2 & 440 \\
Electrical Engineering & 0.06 & -0.38 & 0.5 & -0.43 & 280 \\
English Lang. and Lit. & 0.00 & -0.04 & $-0.14^{*}$ & -0.07 & 736 \\
German Lang. and Lit. & $-0.61^{* * *}$ & -0.13 & -0.3 & -0.19 & 400 \\
History & $-0.48^{* *}$ & -0.19 & -0.32 & -0.21 & 408 \\
Industrial Engineering & -0.02 & -0.17 & 0.16 & -0.17 & 336 \\
Information Systems & -0.07 & -0.27 & -0.09 & -0.36 & 504 \\
Mathematics & -0.44 & -0.26 & -0.24 & -0.23 & 304 \\
Mechanical Engineering & -0.04 & -0.13 & 0.31 & -0.38 & 512 \\
Physics & 0.03 & -0.21 & 0.04 & -0.24 & 728 \\
Political Science & -0.26 & -0.27 & -0.44 & -0.38 & 424 \\
Psychology & -0.06 & -0.2 & -0.32 & -0.22 & 312 \\
Sociology & $-0.42^{* * *}$ & -0.12 & -0.29 & -0.38 & 344 \\
\{Control variables: Year dummies and tuition fee dummies; Pooled estimation: Subject dummies \\
and number of faculties per subject (unbalanced) additionally.Marginal effects and robust standard \\
errors standardized by the standard deviation of the dependent variable\} \\
\end{tabular}

\section{Conclusion}

In this paper, we estimate the short-term effects of the implementation of the Bachelor reform on enrollment and drop-out rates at department level in a fixed effects panel setting. Overall, we do not find a significant change in the number of first-year students due to the implementation of the Bachelor degree in Germany. The reform therefore does not seem to have changed the incentives to pursue higher education at this stage. We do find significantly negative effects of the Bachelor implementation on enrollment for the subjects of electrical, mechanical and industrial engineering as well as for physics. We interpret this result as a possible sign of students avoiding the new degrees in these subjects because the traditional German engineering degrees have a very good reputation. If this is the case, the observed negative effect should eventually vanish as the traditional degrees are increasingly replaced by Bachelor programs. Hence, at the moment we cannot identify any positive or negative impact of the Bachelor introduction with respect to college enrollment, but this may change once the higher education system will be totally reorganised.

With respect to the drop-out rate, we do not find significant effects for most subjects included in our study either. Only business and management 
as well as electrical engineering experience a declining drop-out rate whereas drop-outs are increasing in biology. We have seen that the composition of the student population does not change after the refom, and that the number of students pursuing tertiary education is not significantly affected by the reform. In addition, it seems that the curricula within subjects have not been adjusted in consequence of the Bachelor introduction. Thus, neither the student population nor the curricula seem to have changed a lot and it is therefore plausible that the reform does not affect drop-out rates. Nevertheless, it is important to note that results could change once all departments will have implemented the reform, as only $28 \%$ of the departments introduced the Bachelor reform in 2005, which marks the end of our observation period for the drop-out analysis.

To conclude, at this stage of the reform process, we do not find significant implications of the Bologna Process on college enrollment or drop-out rates for the majority of subjects. Hence, the objective of increasing the number of higher education graduates in order to address the lack of high-skilled personnel could not be achieved so far. But we need to keep in mind that the higher education system has not been totally transformed yet. This is especially relevant for the results regarding the drop-out rates. The effects of the reform on enrollment and drop-out rates may be different in the future, when all departments will have implemented the reform and students cannot choose between the traditional degrees and the Bachelor programs any longer. Therefore, in a next step we plan to integrate the $2007 / 2008$ wave of the administrative data into the analysis in order to observe more departments awarding a Bachelor degree. 


\section{References}

Becker, G. (1964). Human Capital: A Theoretical and Empirical Analysis with Special Reference to Education. University of Chicago Press, 1st edition edition.

Boero, G., Laureti, T., and Naylor, R. (2005). An econometric analysis of student withdrawal and progression in post-reform italian universities. Working Paper CRENos.

Bratti, M., Broccolini, C., and Staffolani, S. (2006). Is '3+2' equal to 4? university reform and student academic performance in italy. Quaderni di Ricerca, 251.

Cappellari, L. and Lucifora, C. (2009). The 'bologna process' and college enrollment decisions. Labour Economics, 16(6):638-647.

Carneiro, P. and Heckman, J. (2002). The evidence on credit constraints in post-secondary schooling. Economic Journal, 112:705-734.

Dearden, L., L-McGranaham, and Sianesi, B. (2004). The role of credit constraints in educational choices: evidence from the ncds and bcs70. CEE Working Paper, 48.

Kehm, B. and Teichler, U. (2006). Which direction for bachelor and master programs? a stock-taking of the bologna process. Tertiary Education Management, 12(4):269-282.

Muehlenweg, A., Sprietsma, M., and Horstschraer, J. (2010). Humankapitalpotenziale der gestuften Hochschulabschlüsse in Deutschland - Auswertungen zu Studienbeteiligung, Studienabbrüchen, Mobilität und Eingangsselektion. Studien zum deutschen Innovationssystem Nr. 14-2010.

Portela, M., Sa, C., Alexandre, F., and Cardoso, A. R. (2009). Perceptions of the bologna process: what do students' choices reveal? Higher Education, 58(4):465-474.

Vandenberghe, V. (2007). Family income and tertiary education attendance across the eu: An empirical assessment using sibling data. CASE Discussion Paper, 123.

Winter, M. V., Cleuvers, B. A., and Anger, Y. (2010). Implikationen der gestuften Hochschul-Curricula auf die Innovationstätigkeit Deutschlands, Qualitative Untersuchungen zur Umstellung der Studien-Curricula in Deutschland. Studien zum deutschen Innovationssystem Nr. 12-2010. 


\section{Appendix}

Figure A.1: Share of departments that implemented the Bachelor reform, by year and subject (1999 - 2006): I

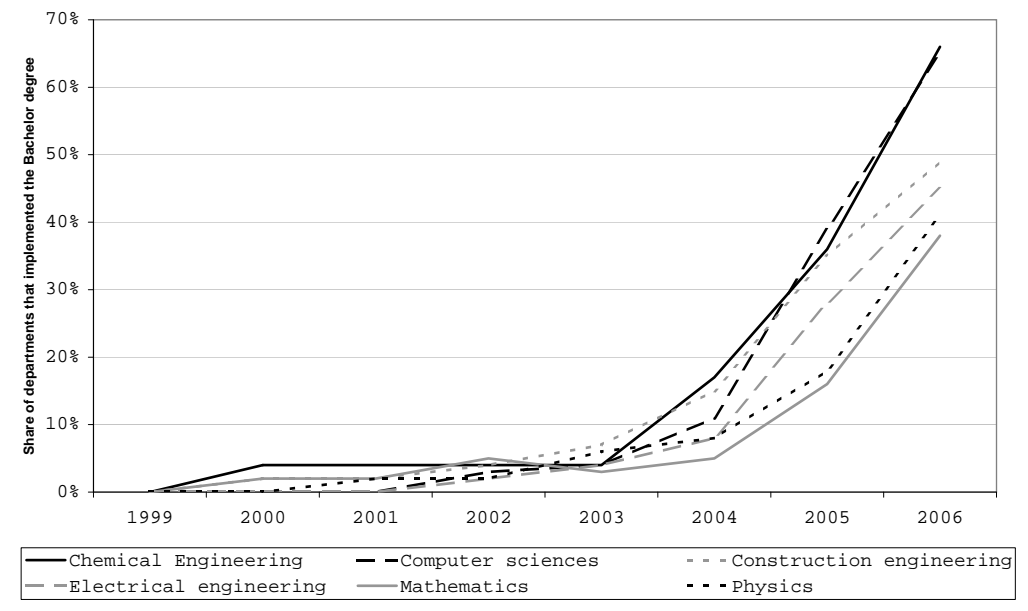

Figure A.2: Share of departments that implemented the Bachelor reform, by year and subject (1999 - 2006): II

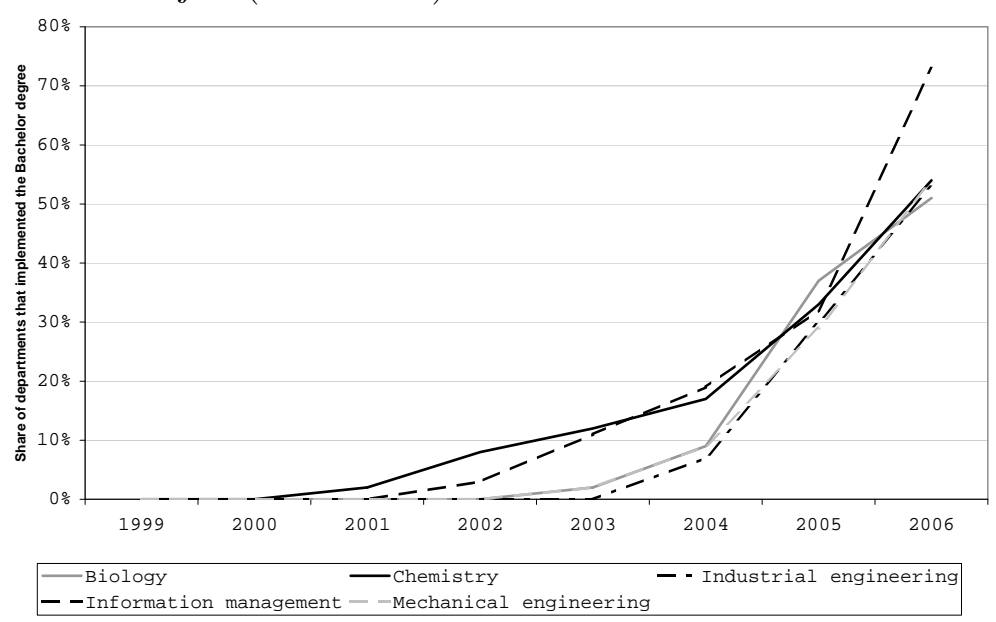


Figure A.3: Share of departments that implemented the Bachelor reform, by year and subject (1999 - 2006): III

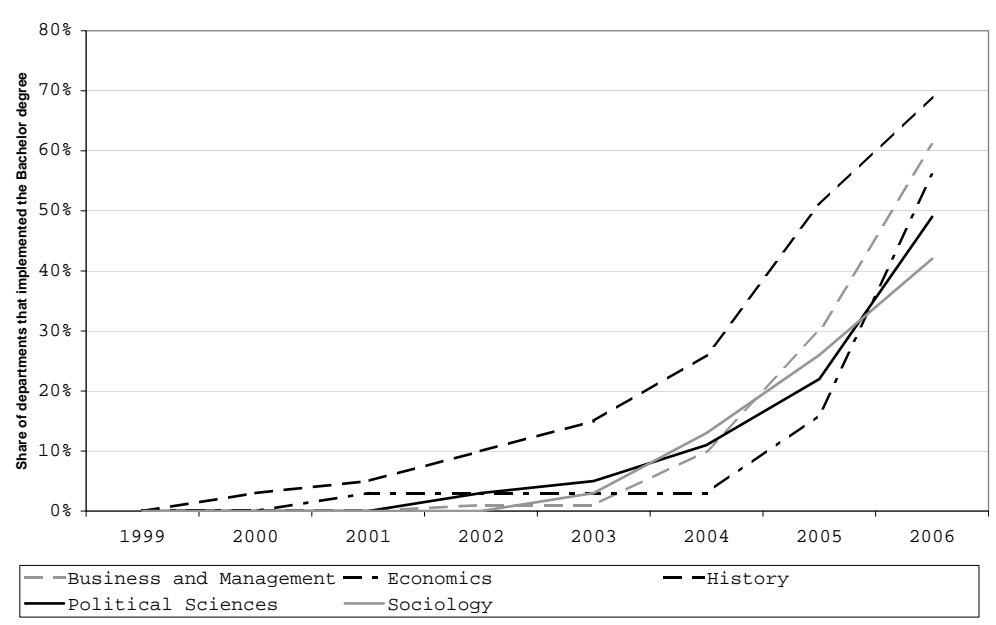

Figure A.4: Share of departments that implemented the Bachelor reform, by year and subject (1999 - 2006): IV

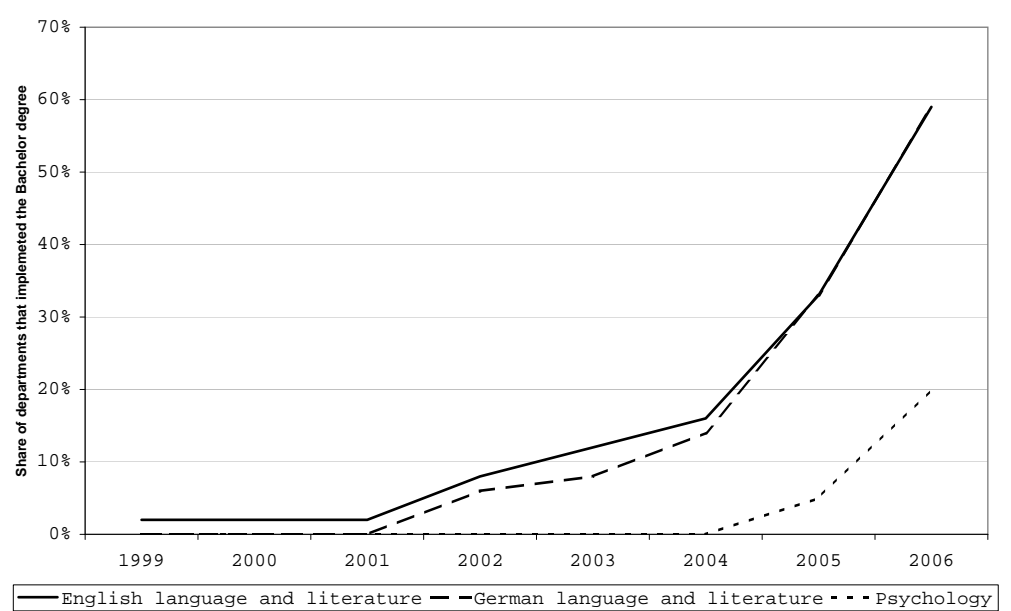

